\title{
PENERAPAN MEDIA KOMIK UNTUK MENINGKATKAN \\ KEMAMPUAN LITERASI DALAM MEMAHAMI SOAL CERITA MATEMATIKA DI SEKOLAH DASAR
}

\section{THE APPLICATION OF COMIC MEDIA TO IMPROVE LITERATURE ABILITY IN UNDERSTANDING MATHEMATICS STORY PROBLEMS IN ELEMENTARY SCHOOL}

\author{
Yani Fitriyani $^{1}$, Marlina Eliyanti ${ }^{2}$, Myrna Apriany Lestari ${ }^{3}$ \\ ${ }^{1}$ Pendidikan Guru Sekolah Dasar STKIP Muhammadiyah Kuningan, \\ ${ }^{2,3}$ Pendidikan Guru Sekolah Dasar Universitas Kuningan \\ ${ }^{1}$ Jl. Syeh Maulana Akbar, Purwawinangun, Kec. Kuningan, Kab. Kuningan, Jawa Barat 45511, \\ 2,3J1. Cut Nyak Dhien No. 36A, Cijoho, Kec. Kuningan, Kab. Kuningan, Jawa Barat 45513 \\ Email: yanifitriyani@upmk.ac.id ${ }^{1}, \underline{\text { marlina@ uniku.ac.id }}^{2}, \underline{\text { myrna@ }}^{\text {uniku.ac.id }}{ }^{3}$
}

Submitted: 27-08-2021, Revised: 01-11-2021, Accepted: 15-11-2021

\begin{abstract}
Abstrak
Penelitian ini berisi tentang kemampuan literasi matematika siswa dalam memahami soal cerita melalui penerapan media pembelajaran komik pada siswa SD Negeri 1 Karangtawang. Penelitian ini bertujuan untuk mendeskripsikan peningkatan kemampuan literasi matematika siswa dalam memahami soal cerita yang menggunakan media komik dengan siswa yang tidak menggunakan media pembelajaran komik. Subjek penelitian siswa kelas V berjumlah 39 siswa. Metode penelitian yang digunakan adalah eksperimen (quasi eksperimental design) dengan nonequivalent control grup design (pretest-postets design). Kelompok eksperimen diberi perlakuan berupa pembelajaran dengan menggunakan media komik dan kelompok kontrol tidak menggunakan media komik. Data dikumpulkan melalui wawancara, dokumentasi, dan tes (pretest-posttest). Hasil analisis menunjukan bahwa: (1) hasil (posttest) kemampuan literasi matematika yang menggunakan media komik lebih tinggi dibandingkan yang tidak menggunakan media komik, dan (2) peningkatan (gain) kemampuan literasi matematika siswa yang menggunakan media komik lebih tinggi atau lebih unggul dibandingkan dengan siswa yang tidak menggunakan media komik. Dari penelitian ini, dapat disimpulkan bahwa terdapat perbedaan hasil (posttest) dan perbedaan peningkatan (gain) dari kedua kelas yang diberi perlakuan berbeda. Siswa dari kelas yang menggunakan media komik dapat meningkatkan kemampuan literasi matematika lebih baik dibandingkan dengan kelas yang tidak menggunakan media komik.
\end{abstract}

Kata Kunci: Komik, Literasi, Matematika

\section{Abstract}

This study discusses the students' mathematical literacy skills in understanding story problems through the application of comic learning media to students of SD Negeri 1 Karangtawang. This study aimed to describe the increase of students' mathematical literacy skills in understanding story problems by using comics media and not using comics learning media. The research subjects of class $V$ consisted of 39 students. The research method used was an experiment (quasi-experimental design) with a nonequivalent control group design (pretest-posttest design). The experimental group was given treatment in the learning by using comic media, and the control group did not use comic media. Data were collected through interviews, documentation, and tests (pretest-posttest). The results of the analysis indicated that: (1) the results (posttest) of the students' mathematical literacy skills by using comic media were higher than not using comics media, and (2) the increase (gain) of the students' mathematical literacy skills using comic media was higher than not using comic media. From this study, it could be concluded that there were differences in the results (posttest) and in the increase (gain) of the two classes that were given different treatments. The students of the class that used comics media could improve their mathematical literacy skills better than the class that did not use comic media. 
Keywords: Comic, Literacy, Mathematics

How to Cite: Fitriyani, Y., Eliyanti, M., \& Lestari, M. A. (2021). Penerapan Media Komik untuk Meningkatkan Kemampuan Literasi dalam Memahami Soal Cerita Matematika di Sekolah Dasar. AULADUNA: Jurnal Pendidikan Dasar Islam, 8(2), 168-179.

\section{Pendahuluan}

Berkembangnya ilmu pengetahuan dan teknologi semakin terlihat maju dari masa ke masa, pada era reformasi ditandai banyaknya informasi dari berbagai media, sehingga menuntut manusia agar mempunyai kemampuan untuk mendapatkan dan menyerap informasi dengan cepat dan lengkap (Mulyani \& Haliza, 2021). Demikian hal tesebut memunculkan daya saing di berbagai aspek, salah satunya yaitu pada aspek pendidikan. Secara umum, pendidikan merupakan proses pembelajaran untuk mempelajari segala hal aspek kehidupan, maka pendidikan adalah salah satu aspek terpenting dan menjadi hak bagi setiap manusia untuk mendapatkannya. Pendidikan seutuhnya adalah suatu rangkaian peristiwa kehidupan yang kompleks, peristiwa itu adalah tahapan proses kegiatan komunikasi sesama manusia guna membentuk pribadi dewasa pada pencapaiannya melalui proses pembelajaran (Arfani, 2016). Berkembangnya negara ditentukan oleh kualitas pendidikan, sehingga untuk meningkatkan kualitas pendidikan, pemerintah melakukan bermacam cara, seperti melakukan pembaharuan pada kurikulum, perubahan sistem penilaian, pengembangan model dan metode pembelajaran, penggunaan media interaktif, dan sumber belajar lain. Media pembelajaran yang diterapkan dalam proses belajar harus mampu menyampaikan materi secara konkret dan sederhana serta mampu membantu guru untuk memberikan pemahaman materi ajar (Maharani, Supriadi, \& Widyastuti, 2018).

Berdasarkan keadaan di lapangan, peneliti menemukan bahwa siswa terlihat mengalami kesulitan dalam proses belajar pada muatan matematika. Matematika yaitu muatan pembelajaran yang pelajari oleh seluruh pelajar mulai dari sekolah dasar sampai jenjang perguruan tinggi (Soedjadi, 2014). Matematika berperan sangat penting dalam kehidupan, siswa harus mampu mempelajari matematika dengan tujuan sebagai bekal untuk pemecahan masalah dalam kehidupannya agar siswa mampu menghadapi perkembangan ilmu yang begitu pesat (Utari, Wardana, \& Damayani, 2019). Salah satu kesulitan yang dihadapi oleh siswa ialah bentuk penyelesaian pada soal cerita. Penyelesaian soal cerita matematika berbeda dengan menyelesaikan soal matematika yang sudah berbentuk bilangan (symbol) matematika (Amfir, 2015). Menurut Karnasih (2015), soal cerita matematika berbentuk kalimat yang memakai bahasa verbal dan pada umumnya berkaitan dengan kehidupan nyata. Pada kegiatan menyelesaikan soal matematika yang berbentuk bilangan atau simbol angka, siswa dapat menyelesaikan dalam waktu yang singkat dengan jawaban yang benar, namun pada soal matematika yang berbentuk soal cerita, mayoritas siswa merasa kesulitan dan berdalih tidak mau mengerjakan karena tidak tahu apa yang akan dilakukan pada soal cerita tersebut. Adapun siswa yang bisa menyelesaikannya yaitu dalam kurun waktu 30 sampai 60 menit dengan jawaban yang kurang tepat.

Peneliti melihat kenyataan di lapangan bahwa pengerjaan soal cerita dalam pelajaran matematika siswa belum menunjukkan hasil yang maksimal. Hal ini dibuktikan dengan hasil rekapitulasi nilai dari jawaban siswa kelas $\mathrm{V}$ dalam menyelesaikan soal cerita matematika di SDN 1 Karangtawang. Nilai siswa diinterpretasikan peneliti pada tabel 1 berikut: 
Tabel 1. Rekapitulasi Jawaban Siswa Kelas V

\begin{tabular}{cccccc}
\hline & Kelas VA & & \multicolumn{3}{c}{ Kelas VB } \\
\hline Jawaban & Siswa & Persentase & Jawaban & Siswa & Persentase \\
\hline Benar & 5 & $25 \%$ & Benar & 7 & $36,8 \%$ \\
\hline Salah & 15 & $75 \%$ & Salah & 12 & $63,2 \%$ \\
\hline Jumlah & 20 & $100 \%$ & Jumlah & 19 & $100 \%$ \\
\hline
\end{tabular}

Dari tabel 1, terbukti kemampuan siswa dalam memahami soal cerita masih relatif rendah, terbukti dengan jawaban siswa kelas VA yang mampu menjawab soal dengan benar hanya 5 siswa atau sebesar $25 \%$ dan ada 15 siswa yang menjawab salah atau sebesar 75\% dari jumlah 20 siswa. Sementara untuk kelas VB yang mampu menjawab soal dengan benar sekitar 7 siswa atau sebesar 36,8\% dan yang menjawab salah ada 12 siswa atau sebesar 63,2\% dari jumlah 19 siswa. Berdasarkan hasil wawancara kepada guru kelas V SDN 1 Karangtawang, diperoleh bahwa dalam kegiatan belajar mengajar terlihat masih rendah pada tingkat pemahaman siswa dalam muatan pelajaran matematika, terutama kemampuan memahami konsep soal cerita. Siswa masih terlihat kesulitan dalam menyelesaikan soal berbentuk cerita yang disajikan guru. Siswa kurang memahami isi soal cerita tersebut dan belum dapat merubahnya ke dalam kalimat matematika. Ditemukan juga bahwa masih terdapat kekeliruan siswa dalam menjawab pertanyaan soal yang diberikan, sehingga apa yang ditanyakan dalam soal dan apa yang dijawab oleh siswa terlihat keliru. Siswa juga kurang mempunyai minat dalam membaca, siswa sering mengatakan malas ketika diberi tugas untuk membaca. Hal ini menyebabkan siswa kesulitan dalam memahami soal yang berbentuk cerita yang pada akhirnya siswa membuat kesalahan pada saat menjawab soal cerita.

Faktor yang menjadikan siswa sulit pada saat menyelesaikan soal cerita matematika ialah kurangnya kemampuan untuk memahami konsep soal cerita tersebut. Kemampuan memahami sebuah konsep diawali dengan sikap siswa terhadap kegiatan membacanya namun siswa malas membaca, terlebih tahap perkembangan kognitif siswa SD ada pada tahap operasional kongkret, sehingga tidak mudah untuk memahami konsepkonsep abstrak secara cepat dan diperlukan bantuan berupa media pembelajaran yang bisa mengemas materi agar mudah dipahami oleh siswa. Rendahnya kemampuan memahami soal cerita akan berpengaruh terhadap kemampuan pemecahan masalah, sementara kegiatan memecahkan masalah merupakan salah satu bagian penting pada muatan ajar matematika (Stacey, 2011). Menurut Jamaris (2015), matematika bertujuan untuk mendorong siswa untuk membiasakan berpikir kritis, logis, dan rasional, sehingga mampu menjadi pemecah masalah. Proses memahami dan menggunakan apa yang diperoleh dari pemahaman matematika untuk memecahkan masalah dalam kehidupan keseharian siswa disebut sebagai kemampuan literasi matematika. Rendahnya tingkat kemampuan siswa dalam memahami konsep soal cerita matematika berpengaruh terhadap kemampuannya dalam pemecahan masalah matematika, yang biasanya menghubungkan masalah di kehidupannya, sehingga dapat dikatakan bahwa kemampuan literasi matematika siswa rendah.

Salah satu solusi dalam mengatasi masalah tersebut, khususnya dalam muatan pembelajaran matematika di SD, yaitu guru melakukan inovasi dengan menggunakan media pembelajaran yang bisa mengemas materi, sehingga mudah dipahami oleh siswa, mendidik secara kreatif, menyenangkan, dan mengaitkan berbagai konsep matematika dengan pengalaman kehidupan siswa yaitu salah satunya media komik. Menurut 
Smaldino (2014), kartun merupakan media yang menarik untuk berbagai usia karena mudah dipahami dan dibaca. Kartun memuat kecerdasan dan kebijakan serta memperkuat sebuah poin dari pengajaran. Riwanto \& Wulandari (2018) mengatakan bahwa penggunaan gambar pada komik memudahkan siswa untuk mendeskripsikan sesuatu yang bersifat abstrak, sehingga sesuai dengan tahapan yang dimiliki siswa sekolah dasar yaitu dalam tahapan operasional konkret (Buchori \& Setyawati, 2015). Komik merupakan salah satu media komunikasi visual yang memiliki kekuatan dalam menyampaikan suatu informasi secara mudah dan dimengerti (Nisak, Arifin, Fahyuni, \& Rahmawati, 2021). Komik merupakan bahan ajar sederhana yang efektif dalam memberikan edukasi bagi pembaca dan sangat membantu dalam membuat konsep pelajaran lebih menarik (Rakhmayanti, 2021; Suhono \& Sari, 2020). Membaca komik dapat menumbuhkan sikap kritis pada anak, menstimulus minat membaca, dan memberikan arahan pada siswa yang tidak suka membaca agar disiplin untuk membaca (Rosyida, Mustaji, \& Subroto, 2018). Definisi literasi adalah kemampuan untuk mendapatkan informasi secara tertulis meliputi tahap keterampilan memahami, mengimplementasikan, dan melakukan refleksi terhadap informasi bacaan sesuai dengan tujuan dalam membacanya (Surya, Poerwanti, \& Sriyanto, 2020). Nurjannah, Wahyudi, \& Setiawan (2018) memberikan penguatan bahwa memanfaatkan komik sebagai media pembelajaran merupakan pilihan yang tepat bertujuan meningkatkan literasi pada siswa. Komik dapat digunakan sebagai media untuk memudahkan siswa untuk berimajinasi terhadap isi dan cerita yang dituangkan (Murti, 2020). Penelitian penggunaan media pembelajaran komik telah dilakukan oleh Daulay (2018) yang menyimpulkan bahwa media komik dapat menstimulus siswa, menarik perhatian, dan memudahkan siswa sekolah dasar untuk belajar, serta menstimulus siswa, sehingga siswa mampu mengingat materi ajar agar lebih mudah. Hasil penelitian tersebut membuktikan media pembelajaran komik telah berhasil meningkatkan kualitas pembelajaran, hal ini menunjukan bahwa siswa dapat memahami materi ajar dengan sangat baik dalam proses pembelajarannya.

Menurut Abidin, Mulyati, \& Yunansah (2021), matematika dari bahasa Yunani adalah mathemata artinya hal yang dipelajari, sedangkan dari bahasa Belanda disebut wiskunde artinya ilmu pasti. Literasi matematis mengandung pengertian sebagai kemampuan dalam memahami dan mempelajari matematika ke dalam segala konteks guna sebagai pemecahan masalah. Berbagai konteks yang meliputi penggunaan bahasa sehari-hari berbentuk lisan dan tulisan yang berisi konsep-konsep matematika, sehingga harus dipahami dari kalimat ke kalimat selanjutnya dan diterjemahkan ke dalam bahasa matematika melalui tahapan yang diawali dengan kemampuan mengidentifikasi dan memahami masalah (Abidin, Mulyati, \& Yunansah, 2021). Hal ini berarti siswa yang mempunyai kemampuan literasi matematis hal ini berarti menunjukan bahwa siswa mempunyai kemampuan dalam membaca, menulis, mendengar, berbicara, dan memiliki pengetahuan matematis, sehingga dapat diimplementasikan untuk memahami, memecahkan masalah, dan mengomunikasikan (Ojose, 2011). Rahardjo, Marsudi, \& Waluyati (2011) menyatakan soal cerita yang ada pada soal matematika ialah pertanyaan yang berkaitan dengan permasalahan pada kehidupan nyata, sehingga dapat dicari pemecahan masalahnya dengan menggunakan kalimat matematika.

Berdasarkan pengertian tersebut, dapat disimpulkan bahwa literasi matematika dalam memahami soal cerita mengandung pengertian sebagai kemampuan siswa dalam memahami matematika dalam berbagai konteks, seperti kemampuan membaca dan mendengar, menulis, dan berbicara, serta pengetahuan matematis terkait dengan suatu permasalahan pada kehidupan nyata, sehingga dapat dicari pemecahan masalahnya 
dengan menggunakan kalimat matematika. Fokus penelitian ini yaitu membaca dan menulis untuk digunakan dalam memahami, menggambarkan, memprediksi, dan menjelaskan suatu fenomena, serta memecahkan masalah dalam kehdupan sehari-hari, sehingga individu dapat bertingkah laku sesuai dengan kehidupan masyarakat. Media komik berbentuk media kartun dengan mendeskripsikan karakter, sehingga dapat memerankan bentuk cerita berbentuk gambar yang disusun guna menghibur para pembaca (Sudjana \& Rivai, 2015).

Media komik dipilih dalam mata pelajaran matematika dikarenakan komik memiliki kelebihan untuk menstimulus minat siswa, sehingga digunakan sebagai solusi dalam memecahkan permasalahan hidupnya. Komik dapat menjadi media penyampaian materi pembelajaran, sehingga lebih menarik. Komik juga digunakan sebagai alat pembantu siswa untuk memahami konsep abstrak dengan jalan cerita yang terdapat pada komik mampu membawakan pesan moral dalam pembelajaran (Yulian, 2018). Bertolak dari hal tersebut, maka tujuan penelitian ini yaitu untuk mendeskripsikan peningkatan hasil kemampuan literasi matematika siswa dalam memahami soal cerita yang menggunakan media komik dengan siswa yang tidak menggunakan media pembelajaran komik.

\section{Metode Penelitian}

Penelitian ini menggunakan pendekatan kuantitatif dengan metode penelitian eksperimen (quasi eksperimental design) dalam bentuk nonequivalent control grup design (pretest postest design). Waktu penelitian dilakukan pada tahun 2020 dengan subjek penelitian kelas VA dan VB berjumlah 39 siswa. Teknik pengumpulan data pada penelitian ini melalui tes bertujuan untuk meningkatkan kemampuan literasi matematika dalam memahami soal cerita pada pembelajaran matematika kelas V di SDN 1 Karangtawang pada muatan materi volume kubus dan balok. Berdasarkan hasil analisis validasi instrumen tes pada skor siswa, dapat disimpulkan soal tes berkriteria baik dan layak digunakan untuk penelitian. Pengolahan data dilakukan dengan analisis uji prasyarat statistik untuk menguji hipotesis dari nilai skor-skor yang diperoleh pada pretest dan posttest.

\section{Hasil dan Pembahasan}

\subsection{Hasil}

Peneliti memberikan soal pretest terlebih dahulu sebelum dilakukan tindakan untuk mendapatkan informasi mengenai kemampuan awal siswa pada kelas ekperimen dan kelas kontrol, adapun paparannya dijabarkan dalam tabel 2 berikut:

Tabel 2. Rekapitulasi Skor Kemampuan Awal Siswa

\begin{tabular}{cccccc}
\hline Kelas & N & Nilai Min & Nilai Max & Rerata & $\begin{array}{c}\text { Standar } \\
\text { Deviasi }\end{array}$ \\
\hline Eksperimen & 20 & 25 & 73 & 50,00 & 12,76 \\
\hline Kontrol & 19 & 13 & 81 & 48,97 & 18,01 \\
\hline
\end{tabular}

Tabel 2 di atas merupakan hasil pra penelitian dengan hasil rerata pada kelas eksperimen dan kelas kontrol menunjukan masih berada dibawah nilai KKM. Peneliti menyimpulkan bahwa kemampuan literasi matematika siswa masih rendah, sehingga mendorong peneliti melakukan perbaikan pada proses belajar matematika. Tindakan yang 
implementasikan peneliti ialah dengan menggunakan media komik dalam pembelajaran. Peneliti menggunakan dua kelas sebagai pembanding untuk mengetahui peningkatannya. Setelah dilakukan proses pembelajaran pada kelas eksperimen yang menggunakan media komik dan kelas kontrol dengan tidak menggunakan media komik, maka dilakukan posttest (tes akhir) untuk mengetahui perbedaan hasil (posttest) pemahaman konsep siswa yang pembelajarannya menggunakan media komik dengan yang tidak menggunakan media komik. Adapun penyajian deskripsi posttest kelas eksperimen dan kelas kontrol dapat dilihat dalam tabel 3 berikut:

Tabel 3. Rekapitulasi Skor Kemampuan Akhir Siswa

\begin{tabular}{cccccc}
\hline Kelas & N & Nilai Min & Nilai Max & Rerata & $\begin{array}{c}\text { Standar } \\
\text { Deviasi }\end{array}$ \\
\hline Eksperimen & 20 & 68 & 91 & 76,55 & 6,09 \\
\hline Kontrol & 19 & 60 & 84 & 70,71 & 8,06 \\
\hline
\end{tabular}

Tabel 3 di atas membuktikan bahwa nilai rerata posttest antara kelas eksperimen dengan kelas kontrol berbeda. Posttest kelas eksperimen memperoleh nilai terendah 68, nilai tertinggi 91, dan reratanya memperoleh 76,55 dengan standar deviasi 6,09. Pada posttest kelas kontrol diperoleh nilai terendah 60 , nilai tertinggi 84 , dan reratanya 70,71 dengan standar deviasi 8,06. Hasil posttest antara kelas eksperimen dan kelas kontrol memiliki perbedaan, yakni terdapat peningkatan dari aspek guru yang telah memahami dan menguasai kelas. Hal ini membuat siswa menjadi lebih mampu menerima materi pelajaran dengan baik. Ini terbukti dari hasil belajar siswa yang telah mengalami peningkatan.

Peneliti juga memperoleh data nilai gain yang diperoleh dari selisih nilai posttest dengan pretest. Peningkatan kemampuan literasi matematika siswa dalam memahami soal cerita dapat dilihat dari gain antara nilai posttest dan nilai pretest dengan menggunakan perhitungan normalisasi gain $(\mathrm{N}$-gain). Tinggi rendahnya gain yang dinormalisasi ( $\mathrm{N}$-gain) dapat dikategorikan kedalam kriteria tinggi, sedang, atau rendah. Hal ini dapat dilihat pada tabel berikut:

Tabel 4. Rekapitulasi N-gain

\begin{tabular}{ccccc}
\hline Kelas & Pretest & Posttest & N-gain & Kriteria \\
\hline Eksperimen & 50,00 & 76,55 & 0,53 & Sedang \\
\hline Kontrol & 48,97 & 70,71 & 0,42 & Sedang \\
\hline
\end{tabular}

Dari tabel 4 di atas, terlihat nilai gain kelas eksperimen sebesar 0,53 berkriteria sedang. Hal ini berarti kemampuan literasi matematika siswa dalam memahami soal cerita di kelas eksperimen meningkat berkriteria sedang. Nilai $\mathrm{N}$-gain kelas kontrol adalah 0,42 berkriteria sedang. Hal ini menunjukan kemampuan literasi matematika siswa dalam memahami soal cerita di kelas kontrol meningkat dengan kriteria sedang. Berdasarkan hasil perhitungan nilai N-gain antara kelas eksperimen dengan kelas kontrol, diperoleh bahwa hasilnya lebih tinggi kelas eksperimen meskipun sama-sama berada dalam kriteria sedang.

Uji perbedaan dua rerata dilakukan dengan tujuan untuk mengetahui perbedaan kemampuan siswa pada kelas eksperimen dan kelas kontrol setelah dilakukan pembelajaran. Hasil uji U diinterpretasikan pada tabel berikut: 
Tabel 5. Uji U Hipotesis Mann Whitney

\begin{tabular}{cccc}
\hline \multirow{2}{*}{ Statistik } & \multicolumn{3}{c}{ Kelas } \\
\cline { 2 - 4 } & Eksperimen & Kontrol \\
\hline Peringkat (U) & $U_{1}=78,5$ & $U_{2}=301,5$ \\
\hline$U_{\text {hitung }}$ & \multicolumn{3}{c}{18,5} \\
\hline$U_{\text {tabel }}$ & \multicolumn{3}{c}{119} \\
\hline Kesimpulan & \multicolumn{3}{c}{$H_{1}$ Diterima } \\
\hline
\end{tabular}

Berdasarkan tabel 5 di atas kesimpulan hipotesis, dilakukan berdasarkan pada kategori pengujian, yaitu jika nilai $U_{\text {hitung }}<$ nilai $U_{\text {tabel }}$, maka $H_{1}$ diterima dan $H_{0}$ ditolak, sedangkan jika nilai $U_{\text {hitung }}>$ nilai $U_{\text {tabel }}$, maka $H_{1}$ ditolak dan $H_{0}$ diterima. Terlihat bahwa data posttest mendapat nilai $U_{\text {hitung }} 78,5$. $U_{1}$ lebih kecil dari $U_{2}(78,5<$ 301,5), sehingga $U_{1}$ digunakan sebagai $U_{\text {hitung. Nilai }} U_{\text {tabel }}$ adalah 119 dan nilai $U_{\text {hitung }}$ dinyatakan < nilai $U_{\text {tabel }}$, maka $H_{1}$ diterima dan $H_{0}$ ditolak. Berdasarkan hal tersebut, dapat disimpulkan bahwa terdapat perbedaan hasil (posttest) kemampuan literasi matematika siswa dalam memahami soal cerita yang menggunakan media komik dengan yang tidak menggunakan media komik.

Pengujian hipotesis kedua yaitu terdapat perbedaan peningkatan (N-gain) kemampuan literasi matematika siswa dalam memahami soal cerita yang pembelajarannya menggunakan media komik dengan yang tidak menggunakan media komik maka dilakukan perhitungan uji U-gain. Nilai gain diperoleh dari selisih skor posttest dan pretest bertujuan mengetahui perbedaan peningkatan kemampuan literasi matematika siswa dalam memahami soal cerita. Hasil perhitungannya dijabarkan dalam tabel berikut:

Tabel 6. Uji U-gain

\begin{tabular}{cccc}
\hline Statistik & \multicolumn{3}{c}{ Kelas } \\
\cline { 2 - 3 } & Eksperimen & Kontrol \\
\hline Peringkat (U) & $U_{1}=88,5$ & $U_{2}=293,5$ \\
\hline$U_{\text {hitung }}$ & & 88,5 \\
\hline$U_{\text {tabel }}$ & \multicolumn{3}{c}{119} \\
\hline Kesimpulan & \multicolumn{3}{c}{$H_{1}$ Diterima } \\
\hline
\end{tabular}

Dari hasil perhitungan uji $U_{\text {gain }}$, diperoleh nilai $U_{\text {hitung }} 88,5$ dengan mengambil taraf signifikasi 5\% diperoleh $U_{\text {tabel }}$ 199. Simpulan hipotesis dihitung berdasarkan kriteria pengujian, yaitu jika nilai $U_{\text {hitung }}<$ nilai $U_{\text {tabel }}$, maka $H_{1}$ diterima dan $H_{0}$ ditolak. Jika nilai $U_{\text {hitung }}>$ nilai $U_{\text {tabel }}$, maka $H_{1}$ ditolak dan $H_{0}$ diterima. Berdasarkan tabel 6 di atas, terlihat bahwa nilai $U_{\text {hitung }}$ dinyatakan lebih kecil dari nilai $U_{\text {tabel }}(88,5<119)$, maka $H_{1}$ diterima dan $H_{0}$ ditolak. Berdasarkan hal tersebut, dapat disimpulkan bahwa terdapat perbedaan peningkatan kemampuan literasi matematika siswa dalam memahami soal cerita yang menggunakan media komik dengan yang tidak menggunakan media komik.

\subsection{Pembahasan}

Pembelajaran dilaksanakan pada dua kelas yaitu kelas eksperimen dengan penggunaan media komik dan kelas kontrol penggunaan media buku. Setelah 
pembelajaran dilaksanakan, siswa diberikan posttest untuk mengetahui kemampuan literasi matematika siswa lalu dilakukan analisis hasil akhir (posttest) dari kedua kelas tersebut. Hasil kesimpulan menunjukkan bahwa kedua kelas menghasilkan peningkatan, namun peningkatan pada kelas eksperimen mendapatkan hasil lebih baik dari pada kelas kontrol. Hal ini dibuktikan dengan hasil skor rerata posttest. Pada kelas eksperimen menunjukkan bahwa posttest kemampuan literasi matematika siswa memiliki rerata sebesar 76,55, sedangkan kelas kontrol menunjukkan bahwa posttest kemampuan literasi matematika siswa memiliki rerata sebesar 70,71. Hal ini juga dibuktikan dengan hasil uji perbedaan posttest dengan menggunakan uji Mann-Whitney yakni $U_{\text {hitung }} 78,5$ dan nilai $U_{\text {tabel }} 119$ atau dengan kata lain $U_{\text {hitung }}$ dinyatakan lebih kecil dari nilai $U_{\text {tabel }}$ hal ini berarti $H_{1}$ diterima dan $H_{0}$ ditolak, artinya terdapat perbedaan hasil (posttest) kelas eksperimen yang menggunakan media pembelajaran komik dengan hasil posttest kelas kontrol yang menggunakan media buku dan perhitungan uji perbedaan peningkatan (gain) melalui uji U-gain menunjukkan nilai $U_{\text {hitung }}$ dinyatakan lebih kecil dari nilai $U_{\text {tabel }}(88,5<119)$, maka $H_{1}$ diterima dan $H_{0}$ ditolak. Hal ini berarti terdapat perbedaan peningkatan kemampuan literasi matematika siswa dalam memahami soal cerita yang mengimplementasikan media komik dengan siswa yang mengimplementasikan media buku. Pada saat tindakan yang dilakukan di SD Negeri 1 Karangtawang, proses pembelajaran dengan implementasi media komik diawali dengan memberikan stimulus kepada siswa dengan memperlihatkan komik dan memberikan gambaran ceritanya. Hal ini membangun rasa ingin tahu siswa terhadap media komik tersebut. Hal ini membuktikan bahwa komik dapat berfungsi sebagai media bacaan yang dapat menjadi jembatan untuk menumbuhkan minat baca siswa (Sudjana \& Rivai, 2015).

Siswa dibagi ke dalam beberapa kelompok dengan menggunakan teknik permainan, kemudian siswa diperbolehkan membaca komik namun dalam waktu yang telah ditentukan. Hal ini memberi peluang agar siswa bertanya bagaimana jalan cerita selanjutnya atau bagaimana cara memecahkan masalahnya terkait cerita yang ada dalam komik tersebut. Komik yang diberikan pada setiap kelompok hanyalah satu komik dengan tujuan agar siswa bisa bekerja sama, namun ternyata hal ini menyebabkan siswa menjadi tidak tertib dan pengetahuan awal mengenai komik tersebut tidak merata. Sebagian besar siswa ingin menjadi pembaca pertama, sebagiannya lagi bersikap acuh tak acuh. Beberapa siswa beranggapan bahwa penyediaan komik hanya satu pada setiap kelompok, jadi tugasnya hanya diwakilkan saja oleh teman kelompoknya. Kemudian metode membaca siswa juga ada yang hanya satu orang membaca nyaring yang lain mendengarkan. Adapun yang membaca satu per satu siswa dan memerlukan durasi waktu yang panjang, padahal waktu yang diberikan oleh peneliti terbatas. Cara mengatasi masalah tersebut pada saat pembelajaran berlangsung peneliti memberikan arahan agar semua siswa wajib membaca komik untuk mengetahui informasi yang terdapat dalam komik dan setiap siswa akan diberikan pertanyaan terkait informasi yang dibaca tersebut. Siswa yang tidak mampu memberikan jawaban dari pertanyaan guru akan diberi punishment berupa tugas rumah. Peneliti juga akan memberikan reward untuk siswa yang aktif dan mengikuti pembelajaran dengan baik, setiap 5 menit berlalu peneliti memberikan aba-aba sisa waktu yang dimiliki siswa untuk membaca, sehingga siswa menjadi terpacu untuk menyelesaikan bacaannya.

Pada pembelajaran kedua, siswa diberikan kesempatan untuk membaca kembali komik tersebut, namun dengan durasi waktu lebih lama. Disini, siswa terlibat diskusi bersama teman kelompoknya terkait permasalahan yang ada dalam cerita, hal ini dapat menumbuhkan sikap kritis terhadap apa yang dibacanya. Jadi komik secara efektif dapat 
digunakan oleh guru sebagai media pembelajaran di sekolah untuk solusi dalam memecahkan permasalahan yang diberikan dalam proses belajar, sejalan yang diungkapkan oleh Rasiman \& Pramasdyahsari (2014) bahwa membaca komik dapat menumbuhkan sikap kritis pada anak, sehingga secara tidak langsung siswa sedang ikut berpikir untuk memecahkan masalah seperti cerita yang ada dalam komik. Dari kedua pembelajaran tersebut, komik mampu menciptakan minat siswa. Media komik dapat membantu guru dalam mengarahkan siswa untuk disiplin membaca, sehingga yang tadinya tidak suka membaca menjadi suka membaca.

Komik sebagai media ajar juga dapat mengemas materi menjadi lebih menarik dilihat dari gambar-gambar yang ditampilkan, karakter tokoh, dan alur ceritanya yang mampu membantu siswa untuk membuka pemahaman terhadap suatu konsep yang sifatnya abstrak. Siswa dapat menggunakan kemampuan matematikanya untuk menyelesaikan masalah dengan cara merumuskan, mengidentifikasi, dan memilih strategi penyelesaian. Secara umum, siswa telah mencapai indikator-indikator literasi matematika hanya pada saat menyusun strategi dalam rangka penyelesaian masalah disertai alasan bahwa siswa masih merasa kesulitan. Kemampuan dasar/pokok dalam proses literasi matematika yang diperoleh dari pengerjaan jawaban siswa pada soal posttest dapat diuraikan sebagai berikut:

a. Komunikasi (Communication)

Siswa kelas eksperimen mampu mengomunikasikan permasalahan dengan menyebutkan pemecahan masalah yang dan membuat rumusan dalam pernyataan, sedangkan untuk kelas kontrol unsur yang diketahui masih belum lengkap dan masih ada yang kurang relevan dengan permasalahan.

b. Matematisasi (Mathematizing)

Siswa kelas eksperimen mampu memahami permasalahan dan menuliskan dalam bahasa matematika (mathematizing horizontal). Hal ini dapat dilihat dari menerapkan rumus-rumus matematika untuk menyelesaikan permasalahan yang disajikan walaupun masih terdapat kesalahan (mathematizing vertikal). Sementara untuk kelas kontrol, sebagian siswa masih belum dapat menuliskan dalam bahasa matematika.

c. Representasi (Representation)

Siswa kelas eksperimen dapat merepresentasikan permasalahan dalam bentuk gambar dan rumus matematika, begitu pula pada kelas kontrol masih terdapat siswa belum mampu merepresentasikan masalah ke dalam bentuk gambar atau rumus.

d. Penalaran dengan Memberi Alasan (Reasoning and Argument)

Siswa kelas eksperimen dapat memberikan penalaran secara logis tentang alasan dari pemilihan strategi yang digunakan dan menghubungkan masalah dengan strategi yang digunakan, sedangkan siswa kelas kontrol sebagian besar merasa bingung dan belum dapat memberikan penalaran secara logis.

e. Strategi pada Pemecahan Masalah (Devising Strategies for Solving Problems)

Siswa kelas eksperimen sudah mampu memikirkan strategi dalam pemecahan masalah yang disajikan, namun masih melakukan kesalahan dalam menggunakan rumus matematika atau dalam perhitungan. Begitu juga dengan kelas kontrol, sebagian siswa masih banyak melakukan kesalahan terhadap penggunaan rumus dan perhitungan.

f. Penggunaan Operasi dan Bahasa Simbol, Bahasa Formal, dan Bahasa Teknis (Using Symbolic, Formal, and Technical Language and Operation)

Siswa kelas eksperimen sudah memahami penggunaan simbol-simbol matematika dan sudah menggunakannya dengan baik untuk membantu penyelesaian permasalahan. 
Namun pada siswa kelas kontrol rerata belum bisa memahami simbol-simbol matematika dan penggunaanya.

g. Penggunaan Alat Matematika (Using Mathematics Tools)

Siswa dapat menggunakan alat matematika yaitu penggaris untuk menggambar kubus dan balok serta kalkulator dalam melakukan perhitungan yang nilainya cukup besar begitu juga dengan kelas kontrol.

Pemaparan di atas menjelaskan bahwa siswa kelas eksperimen mampu mencapai indikator literasi matematika dibandingkan dengan kelas kontrol. Dengan mengidentifikasi unsur, merumuskan masalah, menentukan strategi, menerapkan strategi, dan menginterpretasikan hasil sesuai permasalahan asal, artinya siswa mampu memahami dan menggunakan matematika untuk memecahkan masalah. Pemaparan tersebut menunjukan bahwa sesudah diimplementasikan media komik dalam proses belajar literasi matematika siswa meningkat dibandingkan dengan siswa yang tidak mengimplementasikan media komik, dalam hal ini media buku digunakan sebagai pembanding. Hal ini dapat dibuktikan dengan data yang diperoleh dari hasil analisis nilai gain kelas eksperimen sebesar 0,53 dan kelas kontrol sebesar 0,42. Nilai tersebut selanjutnya diintrepretasikan ke dalam kriteria N-gain, yakni nilai N-gain kedua kelas tergolong sedang namun nilai gain pada kelas eksperimen lebih tinggi dibandingkan dengan kelas kontrol.

\section{Simpulan}

Terdapat perbedaan hasil (posttest) kemampuan literasi matematika siswa dalam memahami soal cerita yang menggunakan media komik dengan siswa yang tidak menggunakan media komik. Hasil penelitian ini dapat menerangkan bahwa penerapan media komik dapat meningkatkan kemampuan literasi matematika siswa dalam memahami soal cerita pada muatan materi kubus dan balok di kelas V sekolah dasar. Terdapat pula perbedaan peningkatan (gain) kemampuan literasi matematika siswa dalam memahami soal cerita yang menggunakan media komik dengan siswa yang tidak menggunakan media komik. Hasil penelitian ini dapat menerangkan bahwa penerapan media komik dapat meningkatkan kemampuan literasi matematika siswa lebih baik atau lebih unggul dalam memahami soal cerita pada materi kubus dan balok di kelas $\mathrm{V}$ siswa sekolah dasar.

\section{Daftar Pustaka}

Abidin, Y., Mulyati, T., \& Yunansah, H. (2021). Pembelajaran Literasi: Strategi Meningkatkan Kemampuan Literasi Matematika, Sains, Membaca, dan Menulis. Bumi Aksara.

Amir, M. F. (2015). Proses Berpikir Kritis Siswa Sekolah Dasar dalam Memecahkan Masalah Berbentuk Soal Cerita Matematika Berdasarkan Gaya Belajar. Jurnal Math Educator Nusantara, 1(2), 159-170. https://ojs.unpkediri.ac.id/index.php/ matematika/article/view/235

Arfani, L. (2016). Mengurai Hakikat Pendidikan, Belajar, dan Pembelajaran. Jurnal PPKn \& Hukum, 11(2), 81-97. https://pbpp.ejournal.unri.ac.id/index.php/JPB/ article/view/5160

Buchori, A., \& Setyawati, R. D. (2015). Development Learning Model of Charactereducation Through E-Comic in Elementary School. International Journal of Education and Research, 3(9), 369-386. https://www.ijern.com/ 
journal/2015/September-2015/30.pdf

Daulay, M. I. (2018). Developing Social Science-History's Comics-Based Learning Media for the Fifth Grade of Primary School In Pekanbaru City. International Journal of Research in Counseling and Education, 1(1), 15. https://doi.org/ 10.24036/008za0002

Jamaris, M. (2015). Kesulitan Belajar Matematika (Perspektif, Asesmen, dan Penanggulangannya). Ghalia Indonesia.

Karnasih, I. (2015). Analisis Kesalahan Newman pada Soal Cerita Matematis. Jurnal Paradikma, 8(1), 37-51. https://doi.org/10.24114/paradikma.v8i1.3352

Maharani, M., Supriadi, N., \& Widyastuti, R. (2018). Media Pembelajaran Matematika Berbasis Kartun untuk Menurunkan Kecemasan Siswa. Desimal: Jurnal Matematika, 1(1), 101-106. https://doi.org/10.24042/djm.v1i1.2036

Mulyani, F., \& Haliza, N. (2021). Analisis Perkembangan Ilmu Pengetahuan dan Teknologi (IPTEK) dalam Pendidikan. Jurnal Pendidikan dan Konseling (JPDK), 3(1), 1001-1109. https://doi.org/10.31004/jpdk.v3i1.1432

Murti, D. K. (2020). Development of Educational Comic with Local Wisdom to Foster Morality of Elementary School Students: A Need Analysis. International Journal of Educational Methodology, 6(2), 337-343. https://doi.org/10.12973/ ijem.6.2.337

Nisak, N. M., Arifin, M. B. U. B., Fahyuni, E. F., \& Rahmawati, I. M. (2021). The Development of Comic Formatted Fiqh Textbook for Islamic Elementary School. European Journal of Education Studies, 8(1), 114-125. https://doi.org/10.46827/ejes.v8i1.3513

Nurjannah, I. F., Wahyudi, \& Setiawan, Y. (2018). Development of Comic with Discovery Learning Model as a Media to Increase Students ' Literacy in Primary School. Jurnal Pendidikan dan Pengajaran, 52(2), 49-61. https://doi.org/ 10.23887/jpp.v52i2.17883

Ojose, B. (2011). Mathematics Literacy: Are We Able to Put the Mathematics We Learn into Everyday Use? Journal of Mathematics Education, 4(1), 89-100. http://educationforatoz.com/images/8.Bobby_Ojose_--_Mathematics_Literacy_ Are_We_Able_To_Put_The_Mathematics_We_Learn_Into_Everyday_Use.pdf

Rahardjo, Marsudi, \& Waluyati, A. (2011). Pembelajaran Soal Cerita Operasi Hitung Campuran di Sekolah Dasar. Pusat Pengembangan dan Pemberdayaan Pendidik dan Tenaga Kependidikan Matematika.

Rakhmayanti, F. (2021). Comic Maker App for Enjoyable Learning. Journal of Physics: Conference Series, 1987(1), 012020. https://doi.org/10.1088/1742-6596/1987/1/ 012020

Rasiman, \& Pramasdyahsari, A. S. (2014). Development of Mathematics Learning Media. International Journal of Education and Research, 2(11), 535-544. https://www.ijern.com/journal/2014/November-2014/44.pdf

Riwanto, M. A., \& Wulandari, M. P. (2018). Efektivitas Penggunaan Media Komik Digital (Cartoon Story Maker) dalam Pembelajaran Tema Selalu Berhemat Energi. Jurnal Pancar, 2(1), 14-18. https://ejournal.unugha.ac.id/index.php/ pancar/article/view/195

Rosyida, A., Mustaji, M., \& Subroto, W. (2018). The Development of Contextual Teaching and Learn-ing-Based Comic as a Learning Media for Elementary School Students. Advace in Social Science, Education, and Humanities Research, 173(ICEI 2017), 13-16. https://doi.org/10.2991/icei-17.2018.4 
Smaldino, S. E. (2014). Intrutional Technology \& Media for Learning. Kencana Prenada Media Grup.

Soedjadi, R. (2014). Inti Dasar-Dasar Pendidikan Matematika Realistik Indonesia. Jurnal Pendidikan Matematika, 1(2), 1-10. https://doi.org/10.22342/jpm.1.2. 807.

Stacey, K. (2011). The PISA View of Mathematical Literacy in Indonesia. Journal on Mathematics Education, 2(2), 95-126. https://doi.org/10.22342/jme.2.2.746.95126

Sudjana, N., \& Rivai. (2015). Media Pengajaran. Sinar Baru Algensindo.

Sugiyono. (2018). Metode Penelitian Kuantitatif, Kualitatif, dan R\&D. Alfabeta.

Suhono, \& Sari, D. A. (2020). Developing Students' Worksheet Based Educational Comic for Eleventh Grade of Vocational High School Agriculture. Anglophile Journal, 1(1), 29-40. https://doi.org/10.51278/ANGLOPHILE.V1I1.78

Surya, A., Poerwanti, J. I. S., \& Sriyanto, M. I. (2020). The Effectiveness of the Use of Digital-Based Educational Comic Media in Improving Reading Interest in Elementary School Students. Proceedings of the 3rd International Conference on Learning Innovation and Quality Education (ICLIQE 2019), 397, 411-415. https://doi.org/10.2991/assehr.k.200129.052

Utari, D. R., Wardana, M. Y. S., \& Damayani, A. T. (2019). Analisis Kesulitan Belajar Matematika dalam Menyelesaikan Soal Cerita. Jurnal Ilmiah Sekolah Dasar, 3(4), 545. https://doi.org/10.23887/jisd.v3i4.22311

Yulian, V. N. (2018). Developing Teaching Materials Using Comic Media to Enhance Students' Mathematical Communication. IOP Conference Series: Materials Science and Engineering, 335(1), 012110. https://doi.org/10.1088/1757-899X/ $335 / 1 / 012110$ 